\title{
Typhoid fever: a global overview
}

Bernard Ivanoff

\begin{abstract}
Abstrak
Penyakit diare masih merupakan masalah kesehatan yang penting, dengan angka kematian sekitar 3 juta setiap tahunnya, dan dari jumlah tersebut diperkirakan 600.000 kematian disebabkan karena demam tifoid (DT). Di sebagian besar negara, puncak insidens DT terjadi pada anak sekolah dengan umur 3-19 tahun. Hal ini menimbulkan suatu pertanyaan apakah bayi dan anak-anak pra sekolah secara relatif terhindar dari DT, karena tidak menelan makanan/minuman yang tercemar dengan kuman penyebab atau mereka juga terinfeksi dengan angka kejadian yang cukup tinggi tetapi karena adanya faktor pejamu yang memberikan respons klinis yang berbeda sehingga tidak terjadi manifestasi klinis yang lazim dari DT. Kemungkinan ini memerlukan suatu penelitian tambahan epidemiologis yang sistematik, dari berbagai lokasi geografis yang berbeda, untuk menentukan apakah fenomena ini terjadi pada semua lokasi endemis DT atau hal ini terjadi karena perbedaan cara-cara pemantauan epidemiologis yang dilakukan selama ini. Timbulnya jenis kuman yang tahan terhadap berbagai jenis antibiotika yang tersebar di Timur Tengah, Asia Selatan dan Tenggara, Afrika bagian Timur Laut, dan yang terakhir dilaporkan dari negara-negara di Asia Tengah, memberikan suatu perangsang untuk menemukan terapi dan vaksin yang efektif terhadap penyakit ini. Dua jenis vaksin yang efektif yang telah mendapat lisensi dan terdapat di pasaran pada saat ini adalah vaksin telan dengan kuman hidup Ty2la yang diberikan 2 hari sekali dengan jumlah 3 dosis, serta vaksin suntik dengan polisakharida Vi dosis tunggal. Target populasi untuk penggunaan kedua jenis vaksin adalah anak-anak sekolah dan bayi yang mendapat imunisasi dengan program EPI. Jenis populasi penting lainnya yang dapat memperoleh manfaat dari penggunaan vaksin adalah para wisatawan dan petugas di laboratorium mikrobiologi. Sebagai penutup, terdapat kebutuhan untuk (i) menentukan beban global DT secara kuantitatif dengan lebih tepat, (ii) menentukan angka kejadian penyakit yang disertai bakteremia pada bayi dan anak kecil, serta (iii) membentuk suatu metoda/alat diagnosis yang mudah dan efektif terhadap penyakit ini.
\end{abstract}

\begin{abstract}
Diarrhoeal diseases are still responsible for about 3 million deaths each year in the world, of which an estimated 600,000 deaths are caused by typhoid fever (TF). In most countries, a peak incidence of TF is reported in school-age children 5-19 years of age. This observation raises the question of whether infants and toddlers are relatively spared from TF because they fail to ingest the vehicles of transmission that infect older persons or whether they in fact become infected at high incidence but certain host factors modify the clinical response such that typical TF does not ensue. This emphasizes the desirability of having additional systemic epidemiological studies from several other geographic regions to document if this phenomenon is common to virtually all TF endemic areas or if it is related to the difference in epidemiological methods. The wide spread emergence of strains resistance to multiple antibiotics throughout the Middle East, South and Southeast Asia, Northeast Africa and most recently Central Asia, stimulated efforts to develop effective treatment and vaccines against this disease. Two effective-vaccines are currently available and licensed: one injectable, Vi polysaccharide, given in one dose and one oral, live Ty2la, given in three doses two days apart. The target population for the use of these vaccines would be schoolage children or infants at EPI imununization time. Other important target populations include travelers and clinical microbiology technicians. In conclusion, there is a need for (i) quantifying in a more precise manner the global burden of TF, (ii) quantifying the incidence of bacteremic disease in infants and toddlers, and (iii) developing simple and effective diagnosis tools.
\end{abstract}

\section{INTRODUCTION}

In the early nineteenth century large-scale human migrations led to rapid increases in the population of cities in Europe and North America, living under crowded conditions in the absence of treated water supplies or sanitation. Thus TF came to be highly endemic in most of these countries. In these regions, in the late nineteenth and early twentieth century ${ }^{l}$ water

Global Programme for Vaccines and Immunization, World Healih Organization, Geneva, Switzerland. treatment ${ }^{2}$ and appropriate sewage disposals led to an impressive decline in the incidence of TF in industrialized countries. However the situation in developing countries was, and is still, very difficult due to financial constraints which makes it almost impossible to provide adequate water treatment and sewage disposal. In such countries TF remains an important public health problem causing high morbidity and mortality 3 with high impact on socioeconomic aspect. Prevention of enteric diseases comprises basic sanitary and hygiene measures, including purifying water supplies, improving water delivery and sewage control. Most of the times, however, it is difficult to properly apply these recommendations. It appears, therefore, that there is a 
need for an effective public health tool to control TF, and the potential use of effective vaccines in appropriate condition should be considered.

\section{EPIDEMIOLOGY}

It is difficult to estimate the real impact of the disease in the world because the clinical picture is, most of the time, confused with many other febrile infections. However it has been estimated that more than 16 million of TF cases occur annually in the world, causing more than 600,000 deaths. These data are based on the literature and the incidence of TF in the control groups during field trials of candidate vaccines evaluated in endemic areas ${ }^{4}$. However it is now widely believed by public health authorities that these estimates of the global burden of TF may have been five to ten times too low. Ideally we think that it would be of high interest to have systematic blood culture surveillance for $\mathrm{TF}$ in multiple areas of several countries including those where TF is not perceived to be a major health problem, as it is in the sites selected for vaccine trials. Data obtained from such systematic surveillance would allow a more realistic estimate to be calculated of the global burden of TF.

In Indonesia, Tadjikistan, Chile, and Peru a high incidence of TF is seen in children from 5 to 19 years of age, whereas infants show much lower incidence rates. This observation raises the question of whether infants and toddlers are relatively spared from TF because they fail to ingest the vehicles of transmission that infect older persons or whether they in fact become infected at high incidence but certain host factors modify the clinical response such that typical TF does not ensue. Another explanation could also be the underestimation of TF cases. A study was conducted in Chile 5 in infants and toddlers brought to health centers who had been checked for blood culture ( $S$. typhi and $S$. paratyphi B) for those who presented high temperature. In some of them (3.5\%), blood cultures were positive and their symptoms were clinically classified as "viral infection". It is important to notice that some countries, like Bangladesh, India Jordan and Iran, reported high incidence in children less than 5 years of age. However it must be emphasized that some of these studies also include patients with enteric fever caused by $S$. parathyphi6.

\section{CONTROL MEASURES}

The current control measures include health education and antibiotics treatment.
Basic measures of sanitation and hygiene includes purifying water supplies, improving water delivery and sewage control, supplying hand-washing facilities, latrines, boiling water and supervising foodhandlers. However, for different reasons, it is difficult to properly apply these measures which showed to be unable to eliminate completely the problem of enteric diseases including TF. Complementary efforts to develop effective tools for public heath control of the disease are needed and essential today.

Since 1948, treatment of patients was usually conducted through oral chloramphenicol which was highly effective in treating acute TF. During the 1960s when chloramphenicol therapy for TF was widespread, Shigella rapidly acquired resistance factor plasmids encoding resistance to chloramphenicol7,8. Chloramphenicol, ampicillin, and co-trimoxazole were widely used and constituted the so called "first-line antibiotics against $S$. typhi". However, since 1960 progressive resistance to 1 or 2 of these first line antibiotics has been reported. Circa 1990, sporadic cases and localized outbreaks began to appear caused by strains of S. typhi encoding plasmid-mediated resistance to trimetho-

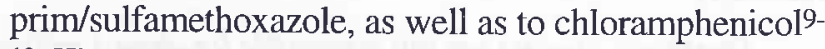
13. Therapy of such strains requires the use of quinolone antibiotics such as oral ciprofloxacin or third generation cephalosporins such as parenteral ceftriaxone, antibiotics that are costly for developing countries. However, the need for increasing doses of ciprofloxacin has been reported from India and resistance to nalidixic acid and ciprofloxacin itself has yet been described in patients returning to the UK from India ${ }^{14}$. In contrast with previous antibiotic-resistant strains that caused sporadic cases or extended epidemics, as in Mexico from 19721973 and Peru from 1979-1981, and that eventually disappeared to be replaced once again by sensitive strains, the multiply-resistant $S$. typhi strains that appeared in the Middle East and the Indian sub-continent circa 1990 are still the dominant strains in those areas. Moreover, these multiply-resistant strains have spread widely and are prevalent in northeast Africal3 and southeast Asia15,16.

It appears that $S$. typhi manifesting resistance to multiple, previously useful antibiotics may be here to stay. Thus, once again, typhoid fever is no longer a simple, inexpensive disease to treat with oral antibiotics so that health authorities can base control programs in large part on early treatment of disease. Complications of typhoid fever and deaths are on the increase because of inappropriate, delayed or inadequate antibiotic therapy $9,10,17,18$. 


\section{VACCINES}

Because this topic will be discussed by other presenters, we will not go into details, but just mention the current available vaccines, licensed and already widely used by travelers. Two vaccines are currently available, one injectable (Vi polysaccharide vaccine) given in one dose and another oral (Ty21a) given in three doses two days apart. Both are effective and very well tolerated 19 . A large field trial evaluation was done in 200,000 children 20 showing that vaccination in school-aged children would be practical and realistic; unfortunately there is a lack of programmatic use of these vaccines for controlling $\mathrm{TF}$.

Microbiologist, travelers, people in refugee camps, and children could represent the target population for vaccination. Should the incidence of TF be confirmed during the school years in children between 5 to 19 years of age, the best time to immunize would be school time. Potential vaccines to be used would be either Vi or Ty21a. Should the incidence be reported in children less than 5 years of age, the EPI time should be more appropriated using a Vi-conjugate vaccine. Recommendation for using vaccines against TF for routine prevention programmes have previously been presented 19 .

\section{NEEDS FOR THE FUTURE}

Two epidemiologic questions beg to be answered in a definitive manner to provide information that will help direct international efforts to control TF. The first relates to updating the real burden of TF in most of the developing countries. The second concerns the precise evaluation of the incidence of the disease in infancy, in conducting bacteremic determination in infants and toddlers less than 2 years of age.

Should the target age from 5 to 19 years be confirmed, it would be of high interest that one or several countries undertake demonstration projects based on school immunization with the currently available vaccines. For countries where the target age is in children less than 5 years of age, TF vaccines should be administered during EPI schedule, with DTP vaccine for a multidose vaccine or at measles time for a one dose vaccine. In any case, there is a need for data to show that if these vaccines are given to infants they would elicit enduring protective immunity that would protect years later when the children reach the school age years.

Another need concerns the potential use of TF vac- cines in an outbreak situation. No data exist to know whether or not the use of TF vaccines could be an effective tool for controlling the epidemic. Usually the strains responsible for epidemic are multidrugs resistant and raised the question of the interest of preventive measures like vaccination to control the disease. Cost effectiveness studies could be conducted to have information helping decision makers in their recommendation.

Finally there is a need for a simple and effective tool for diagnosis of the disease for epidemiological application (disease burden or follow up of a field trial on vaccine efficacy).

\section{CONCLUSION}

Morbidity and mortality from typhoid fever remain an important problem for public health authorities in developing countries. Control of the disease was conducted with effective antibiotics, unfortunately the emergence and the world-wide spread of $S$. typhi strains that are resistant to most previously useful antibiotics raises again the question of an effective tool for controlling this disease. As a consequence, there is renewed interest to better understand the epidemiology of typhoid fever and some aspects of its pathogenesis. More importantly, perhaps, there is much pre-occupation in exploring expanded roles for typhoid vaccines. One important challenge for public health authorities is to devise ways to utilise the two currently available improved typhoid vaccines, oral Ty21a and parenteral Vi polysaccharide, in largescale school-based immunisation programs and monitor the public health impact. Since humans constitute the reservoir of typhoid infection through short-term and long-term carriers, vaccines that actually prevent infection with wild type $S$. typhi as well as conferring protection against clinical illness can, if used in conjunction with other control measures, help eradicate $S$. typhi disease even in less-developed regions of the world.

\section{REFERENCES}

1. JAMA. Typhoid in the large cities of the United States in 1919. JAMA 1920; 672-5.

2. Wolman A, Gorman A. The significance of waterborne typhoid fever outbreaks. Baltimore, Williams \& Wilkins 1931.

3. Edelman R, Levine MM. Summary of an international workshop on typhoid fever. Rev Infect Dis 1986; 8: 329-49.

4. Ivanoff B, Levine MM. Typhoid Fever: Continuing challenges from a resilient bacterial foe. Bull Inst Past/Res Infect Dis 1997; 95 (3): 
5. Ferreccio C, Levine MM, Manterola A, Rodriguez G, Rivara I, Prenzel I, et al. Benign bacteremia caused by Salmonella typhi and paratyphi in children younger than 2 years. J Pediatr 1984; 104: 899-901.

6. Mahle WT, Levine MM. Salmonella typhi infection in children younger than five years of age. Pediatr Infect Dis J 1993; 12 (8): 627-31.

7. Olarte J, De la Torre JA. Resistance of Shigella flexneri to tetracyclines, chloramphenicol and streptomycin. Am J Trop Med Hyg 1959; 8: 324-6.

8. Mitsuhashi S. The R factors. J Infect Dis 1969; 119: 89-100.

9. Gupta A. Multidrugresistant typhoid fever in children: epid̨emiology and therapeutic approach. Pediatr Infect Dis 1994; 13: 124-40.

10. Bhutta ZA, Naqvi SH, Razzaq RA, Farooqui BJ. Multidrugresistant typhoid in children: presentation and clinical features. Rev Infect Dis 1991; 13: 832-6.

11. Rowe B, Ward LR, Threlfall EJ. Spread of multiresistant Sal monella typhi. Lancet 1990; 336: 1065-6.

12. Mikhail IA, Haberberger RL, Farid Z, Girgis NI, Woody JN. Antibioticmultiresistant Salmonella typhi in Egypt. Trans R Soc Trop Med Hyg 1989; 83: 120.

13. Anand AC, Kataria VK, Singh W, Chatterjee SK. Epidemic multiresistant enteric fever in eastern India [letter]. Lancet 1990; 335: 352.

14. Umasankar S, Wall RA, Berker J. A case of Ciprofloxacin resistant typhoïd fever. Communicable Disease Report 1992; 2 : 139-40.

15. Nguyen TA, Ha Ba K, Nguyen TD. [Typhoid fever in South Vietnam, 1990-1993]. Bull Soc Pathol Exot 1993; 86: 476-8.

16. Vinh H, Wain J, Vo TN, Cao NN, Mai TC, Bethell D, et al. Two or three days of ofloxacin treatment for uncomplicated multidrug resistant typhoid fever in children. Antimicrob Agents Chemother 1996; 40: 958-61.

17. Singh $M$. The challenge of multidrug resistant typhoid fever [editorial]. Indian Pediatr 1991; 28: 329-32.

18. Bhutta ZA. Impact of age and drug resistance on mortality in typhoid fever. Arch Dis Child 1996; 75: 214-7.

19. Ivanoff $B$, Levine MM, Lambert $P H$. Vaccination against typhoid fever: present status. Bull Wld Hlth Org 1994; 72: 95771.

20. Ferreccio C, Levine MM, Rodriguez H, Contreras R. Comparative efficacy of two, three, or four doses of TY21a live oral typhoid vaccine in entericcoated capsules: a field trial in an endemic area. J Infect Dis 1989; 159: 766-9. 